\title{
Assessing the Respiratory Effects of Air Pollution from Biomass Cookstoves on Pregnant Women in Rural India
}

\author{
Raj Parikh ${ }^{1, *}$, Sowmya R. Rao ${ }^{2}$, Rakesh Kukde ${ }^{3}$, George T. O'Connor ${ }^{1}$, Archana Patel ${ }^{3}$ and Patricia L. Hibberd ${ }^{2}$ \\ 1 Division of Pulmonary and Critical Care Medicine, Boston University School of Medicine, Boston University \\ Medical Center 72 East Concord Street, R304, Boston, MA 02118, USA; goconnor@bu.edu \\ 2 Department of Global Health, Boston University School of Public Health, Boston, MA 02118, USA; \\ srrao@bu.edu (S.R.R.); plh0@bu.edu (P.L.H.) \\ 3 Lata Medical Research Foundation, Nagpur 440002, India; rajahal3@gmail.com (R.K.); \\ dr_apatel@yahoo.com (A.P.) \\ * Correspondence: Raj.parikh210@gmail.com; Tel.: +617-358-1340; Fax: +617-353-1337
}

check for

updates

Citation: Parikh, R.; Rao, S.R.; Kukde, R.; O'Connor, G.T.; Patel, A.; Hibberd, P.L. Assessing the Respiratory Effects of Air Pollution from Biomass Cookstoves on Pregnant Women in Rural India. Int. J. Environ. Res. Public Health 2021, 18, 183. https://doi.org/ 10.3390/ijerph18010183

Received: 5 December 2020 Accepted: 24 December 2020 Published: 29 December 2020

Publisher's Note: MDPI stays neutral with regard to jurisdictional clai$\mathrm{ms}$ in published maps and institutional affiliations.

Copyright: (C) 2020 by the authors. Licensee MDPI, Basel, Switzerland. This article is an open access article distributed under the terms and conditions of the Creative Commons Attribution (CC BY) license (https:// creativecommons.org/licenses/by/ $4.0 /)$.

\begin{abstract}
Background: In India, biomass fuel is burned in many homes under inefficient conditions, leading to a complex milieu of particulate matter and environmental toxins known as household air pollution (HAP). Pregnant women are particularly vulnerable as they and their fetus may suffer from adverse consequences of HAP. Fractional exhaled nitric oxide (FeNO) is a noninvasive, underutilized tool that can serve as a surrogate for airway inflammation. We evaluated the prevalence of respiratory illness, using pulmonary questionnaires and FeNO measurements, among pregnant women in rural India who utilize biomass fuel as a source of energy within their home. Methods: We prospectively studied 60 pregnant women in their 1st and 2nd trimester residing in villages near Nagpur, Central India. We measured FeNO levels in parts per billion (ppb), St. George's Respiratory Questionnaire (SGRQ-C) scores, and the Modified Medical Research Council (mMRC) Dyspnea Scale. We evaluated the difference in the outcome distributions between women using biomass fuels and those using liquefied petroleum gas (LPG) using two-tailed t-tests. Results: Sixty-five subjects (32 in Biomass households; 28 in LPG households; 5 unable to complete) were enrolled in the study. Age, education level, and second-hand smoke exposure were comparable between both groups. FeNO levels were higher in the Biomass vs. LPG group (25.4 ppb vs. $8.6 \mathrm{ppb}$; $p$-value $=0.001$ ). There was a difference in mean composite SGRQ-C score (27.1 Biomass vs. 10.8 LPG; $p$-value < 0.001) including three subtotal scores for Symptoms (47.0 Biomass vs. 20.2 LPG; $p$-value< 0.001), Activity (36.4 Biomass vs. 16.5 LPG; $p$-value $<0.001$ ) and Impact (15.9 Biomass vs. 5.2 LPG; $p$-value < 0.001). The mMRC Dyspnea Scale was higher in the Biomass vs. LPG group as well ( 2.9 vs. $0.5 ; p<0.001)$. Conclusion: Increased FeNO levels and higher dyspnea scores in biomass-fuel-exposed subjects confirm the adverse respiratory effects of this exposure during pregnancy. More so, FeNO may be a useful, noninvasive biomarker of inflammation that can help better understand the physiologic effects of biomass smoke on pregnant women. In the future, larger studies are needed to characterize the utility of FeNO in a population exposed to HAP.
\end{abstract}

Keywords: household air pollution; biomass fuel; fractional exhaled nitric oxide; Central India; indoor air pollution

\section{Introduction}

An estimated half of the world's population, predominantly in low-middle income countries, utilizes biomass fuels as their main source of energy for cooking, heating, and lighting [1,2]. Biomass fuels such as woody fuels and animal wastes are organic materials. Biomass fuel is burned in the home under inefficient conditions, leading to a complex milieu of particulate matter and environmental toxins known as household air pollution (HAP). HAP, despite being a modifiable and preventable risk factor in the global burden of disease, has been identified by the WHO as a major cause of morbidity worldwide behind 
unsafe drinking water and sanitation [3-5]. In 2018, the WHO estimated that 3 billion people cook using biomass fuels [3]. Furthermore, almost 4 million people die from HAP annually as a result of pneumonia, chronic obstructive lung disease (COPD), lung cancer, and other medical complications [3].

Due to time spent in the household, pregnant women are particularly vulnerable to HAP [6,7]. They and their fetus may suffer adverse consequences of exposure to biomass smoke [8-15]. For these women, exposure to biomass smoke increases the risk of anemia, cardiovascular disease, and perinatal complications $[10,16]$. The toxic air particles can not only cause deficits in lung function but also cross the placenta and reduce oxygen delivery to the fetus $[11,17,18]$. Increased levels of these pollutant components result in decreased birth weight, height, and head circumference while also serving as a risk factor for preterm birth [11,17,19-23]. Carbon monoxide (CO), in particular, is a health-damaging airborne pollutant that can reduce oxygen delivery to the fetal circulation thereby causing tissue hypoxia [24-27].

The underlying mechanisms of pulmonary disease as a consequence of air pollution are believed to be directly related to airway inflammation [28-32]. Established evidence suggests that an environmental exposure may result in increased reactive oxygen species and an upregulation of proinflammatory cytokines [33-35]. In order to assess this subclinical airway inflammation, fractional exhaled nitric oxide (FeNO) has recently been utilized in air pollution studies [33,36-43]. FeNO measurements quantify the amount of nitric oxide (NO) in one's exhaled breath to indicate eosinophilic inflammation as a result of cytokines and Type 2 helper cells (Th2) [44-47]. As detailed by Allen et al., FeNO has been studied extensively in asthmatics as well as in COPD, cystic fibrosis, and bronchiectasis and is often referred to as a surrogate for airway inflammation [48].

Due to the deleterious effects of HAP in both the adult and pediatric population, the Indian government initiated a scheme in 2015 to provide subsidized clean fuel to those in the community who could not afford it. Liquefied petroleum gas (LPG), a mixture of propane and butane, is a clean and efficient fuel that the Indian government has utilized as a versatile energy source for those living below the poverty line. However, despite the subsidization of LPG, many households continue to use biomass fuel as a primary source of energy [49].

The objective of our study was to assess the burden of respiratory symptoms and airway inflammation, measured by FeNO levels, among pregnant women in rural India who utilize biomass fuel within their home, irrespective of individual cookstove design. We assessed whether the distribution of (i) FeNO measurements, (ii) self-reported St. George's Respiratory Questionnaire (SGRQ-C) scores, and (iii) Modified Medical Research Council (mMRC) Dyspnea Scale varied substantially between women who lived in households using biomass fuel for cooking and those who used only LPG. A secondary objective was to assess the relationship of FeNO measurements with mMRC scores.

\section{Materials and Methods}

We conducted a cross-sectional study in rural villages near Nagpur, India. The study protocol was approved by the Institutional Review Boards of Boston University Medical Center and Lata Medical Research Foundation (H-38568). All study participants provided informed consent.

\subsection{Study Setting}

The study was conducted at government-established primary health centers (PHC) in seven rural villages within a $100-\mathrm{km}$ radius of Nagpur, India. Nagpur is home to approximately 2.4 million people, where approximately $36 \%$ of the population lives in low-income communities. 


\subsection{Participants}

Pregnant women within the first and second trimester of pregnancy, as defined by last menstrual period, were included in the study. Those in their third trimester were excluded as there is limited evidence regarding the physiologic changes of pregnancy that are heightened in the third trimester and its effects on FeNO testing. Subjects were considered ineligible if they reported a prior history of cardiopulmonary disease, were not planning to have all of their antenatal care in the Nagpur area, or were smoking tobaccorelated products. The 65 women enrolled in the study were stratified into two primary groups based on the self-reported type of cooking fuel used in the household: (i) mainly biomass; (ii) only LPG. Information regarding type of cookstove being used, other than the primary fuel source, was not recorded.

\subsection{FeNO Testing}

FeNO testing with NIOX VERO (NIOX, Circassia, UK) was conducted during each visit. Participants sat upright, emptied their lungs, inhaled steadily through the NIOX VERO, and then exhaled at a slow and steady rate for $10 \mathrm{~s}$. Each study participant performed two tests and the results of which were deemed satisfactory by the trained physicians conducting the test; the final FeNO measurement was the average of both tests. Satisfactory scores were defined as those that resulted in appropriate exhalation waveforms that triggered the device to provide a FeNO value, measured as parts per billion (ppb). FeNO testing was conducted by a trained pulmonary physician from Boston University Medical Center and a trained cardiology physician employed by the Lata Medical Research Foundation.

\subsection{Subjective Testing}

The SGRQ was originally designed to measure health impairment in patients with asthma and COPD. This respiratory questionnaire has been previously utilized and proven successful in low-resource areas of India [50-52]. The SGRQ-C is a shorter questionnaire derived from the original version following detailed data analysis of large studies in COPD [53]. The SGRQ-C was adapted for our study in an effort to obtain a subjective assessment of each participants' respiratory status. The questionnaire included 14 prompts ( 9 multiple choice questions and 5 true versus false questions) and the first section focused on respiratory symptoms such as cough, phlegm production, shortness of breath, and wheezing. Two additional sections assessed the subjects' quality of life and exercise capacity as it pertained to their respiratory status. The SGRQ-C was translated into Hindi and Marathi by the publisher and was completed by each participant individually. The SGRQ-C scoring tool, provided by the publisher, was used to create four scores: Symptoms, Activity, Impact, and Composite. The adjusted scores were computed based on the methodology provided by St. George's University of London and the higher scores indicate worse functionality [54]. The mMRC scale was also used as a second subjective assessment of the participants' symptoms [55]. The mMRC scale is a self-rating tool that is used to measure the degree of dyspnea that affects daily activities. The scale ranges from 0 to 4 with the higher number implying more severe respiratory symptoms.

\subsection{Covariates}

Age, body mass index (BMI) recorded at initial prenatal visit, level of education, prior pregnancy history, location of cookstove within or outside the home, and secondhand smoking status were recorded for each woman participating in the study. This was completed using an interviewer-administered questionnaire designed specifically for the study.

\subsection{Statistical Analysis}

Summary statistics (e.g., proportion, mean, standard deviation (SD)) were obtained on all variables. As appropriate, statistical significance of group differences were tested with 
Fisher's exact tests (categorical variables) and Kruskal-Wallis tests (continuous variables). Pearson correlations were used to quantify the linear relationship between Mean FeNO and mMRC. All analyses were performed using SAS 9.4 (SAS Institute, Cary, NC, USA) with a two-sided $p<0.05$ considered statistically significant.

\section{Results}

Of the 110 subjects prescreened, 65 eligible subjects were enrolled (Figure 1). We excluded 5 subjects ( 3 in the biomass group, 2 in the LPG group) unable to follow instructions for FeNO testing. Of the 60 subjects, 28 lived in households using only LPG, 9 in households using only Biomass, and 23 in households using Biomass with LPG. We combined the last two groups since the distribution of the measurements in these groups was similar; this combined group was referred to as Biomass while the only LPG group was referred to as LPG.

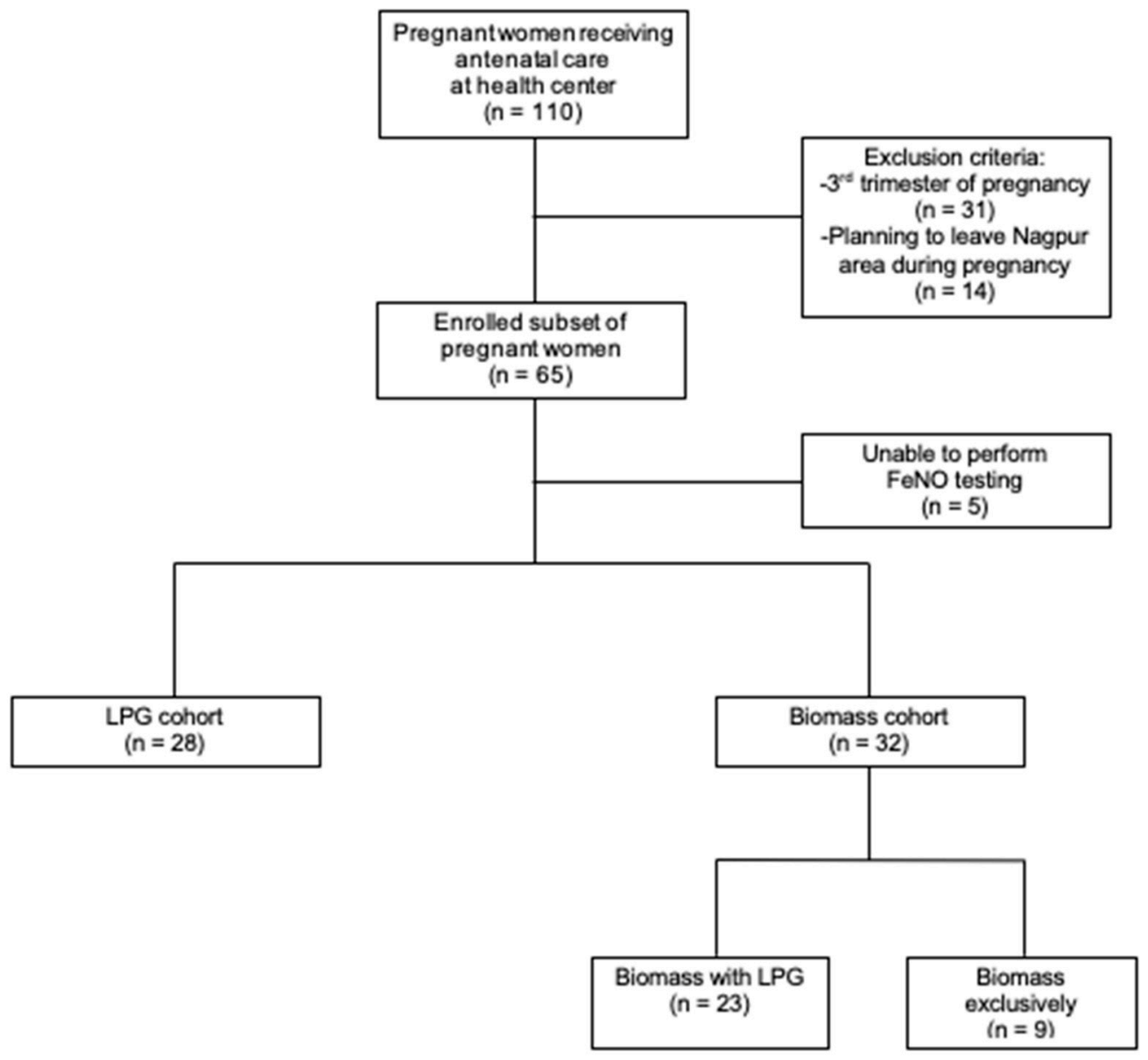

Figure 1. Consort diagram.

The distribution of baseline participant characteristics including age, BMI, level of education, and second-hand smoke exposure were similar in the LPG and Biomass groups (Table 1). Of note, $40.6 \%(\mathrm{n}=13)$ of women in the Biomass group had a history of preterm birth compared to only $7.1 \%(n=2)$ of women in the LPG group, similar to findings previously well-established by our co-investigators [8]. The majority of participants reported that their cookstove was physically located within the home (84.4\% in Biomass; $96.4 \%$ in LPG) and not in a separate building. Among those using biomass, wood was the most common source of biomass fuel $(75.0 \%)$. 
Table 1. Participant characteristics. LPG: liquefied petroleum gas.

\begin{tabular}{|c|c|c|c|}
\hline Participant Characteristics & Biomass $(n=32)$ & LPG $(n=28)$ & $p$-Value \\
\hline Mean age (SD) & $23.3(3.0)$ & $23.4(3.1)$ & 0.987 \\
\hline Mean BMI (SD) & $19.7(2.1)$ & $18.9(1.6)$ & 0.109 \\
\hline \multicolumn{4}{|l|}{ Education } \\
\hline Primary & $9(28.1 \%)$ & $8(28.6 \%)$ & \multirow{3}{*}{1.0} \\
\hline Secondary & $12(37.5 \%)$ & $10(35.7 \%)$ & \\
\hline College & $11(34.4 \%)$ & $10(35.7 \%)$ & \\
\hline \multicolumn{4}{|l|}{ Parity } \\
\hline Nulliparous & $16(50.0 \%)$ & $15(53.6 \%)$ & \multirow[t]{2}{*}{0.802} \\
\hline Multiparous & $16(50.0 \%)$ & $13(46.4 \%)$ & \\
\hline Preterm birth history & $13(40.6 \%)$ & $2(7.1 \%)$ & 0.003 \\
\hline \multicolumn{4}{|l|}{ Second hand smoke } \\
\hline Daily & $15(46.9 \%)$ & $13(46.4 \%)$ & \multirow{3}{*}{0.946} \\
\hline Weekly/Monthly & $8(25.0 \%)$ & $6(21.4 \%)$ & \\
\hline Never & $9(28.1 \%)$ & $9(32.1 \%)$ & \\
\hline \multicolumn{4}{|l|}{ Biomass fuel type } \\
\hline Wood & $24(75.0 \%)$ & \multirow{3}{*}{\multicolumn{2}{|c|}{ Not applicable }} \\
\hline Crop/grass & $3(9.4 \%)$ & & \\
\hline Cow dung & $5(15.6 \%)$ & & \\
\hline \multicolumn{4}{|l|}{ Secondary fuel type } \\
\hline Crop/grass & $22(68.8 \%)$ & \multirow{2}{*}{\multicolumn{2}{|c|}{ Not applicable }} \\
\hline Cow dung & $3(9.4 \%)$ & & \\
\hline \multicolumn{4}{|l|}{ Fuel source timeframe } \\
\hline$<3$ years & $4(12.5 \%)$ & $18(64.3 \%)$ & \multirow[t]{2}{*}{$<0.001$} \\
\hline$\geq 3$ years & $28(87.5 \%)$ & $10(35.7 \%)$ & \\
\hline \multicolumn{4}{|l|}{ Stove location within home } \\
\hline Within home & $27(84.4 \%)$ & $27(96.4 \%)$ & \multirow[t]{2}{*}{0.201} \\
\hline Separate room & $5(15.6 \%)$ & $1(3.6 \%)$ & \\
\hline
\end{tabular}

As mentioned above, FeNO testing was conducted for each participant until two satisfactory scores were obtained with appropriate exhalation curves. Multiple attempts at obtaining FeNO measurements were required for $47 \%$ of the Biomass group and $53.6 \%$ of the LPG group. The mean FeNO score for the Biomass group was $25.4 \mathrm{ppb}$ compared to $8.6 \mathrm{ppb}$ in the LPG subgroup $(p<0.001$; Table 2$)$.

Table 2. St. George's Respiratory Questionnaire (SGRQ-C) scores, Modified Medical Research Council (mMRC) dyspnea scale, and mean fractional exhaled nitric oxide ( $\mathrm{FeNO}$ ) results between the Biomass and LPG groups of the study.

\begin{tabular}{cccc}
\hline SGRQ-C, mMRC, FeNO Scores & Biomass $(\mathbf{n}=\mathbf{3 2})$ & LPG $(\mathbf{n}=\mathbf{2 8})$ & $p$-Value \\
\hline SGRQ-C Symptoms & $47.0(5.5)$ & $20.2(11.1)$ & $<0.001$ \\
SGRQ-C Activity & $36.4(8.5)$ & $16.5(9.0)$ & $<0.001$ \\
SGRQ-C Impact & $15.9(4.7)$ & $5.2(3.5)$ & $<0.001$ \\
SGRQ-C Composite & $27.1(3.8)$ & $10.8(4.0)$ & $<0.001$ \\
Mean mMRC & $2.9(0.9)$ & $0.5(0.6)$ & $<0.001$ \\
FeNO (first test) ppb & $25.4(7.9)$ & $8.6(3.2)$ & $<0.001$ \\
FeNO (second test) ppb & $25.4(8.1)$ & $8.6(3.1)$ & $<0.001$ \\
\hline
\end{tabular}

The SGRQ-C assessed three primary groups of respiratory health, based on the participants' symptoms, activity tolerance, and impact or quality of life. On average, the Biomass group had higher adjusted scores than the LPG group (Symptom: 47.0 vs. 20.2; Activity: 36.4 vs. 16.5 ; Impact: 15.9 vs. 5.2 ; Composite: 27.1 vs. 10.8 ; all $p<0.0001$; Table 2). In particular, the Biomass group reported more symptoms (Tables 3 and 4) than the LPG 
group for cough (41.6 vs. 21.0; $p<0.0001$; Table 4), phlegm production (44.4 vs. 20.7; $p<0.001)$, and shortness of breath (46.3 vs. 18.0; $p<0.001)$. Both groups scored similarly for wheezing (5.7 in Biomass vs. 5.2 in LPG; $p=0.89$ ).

Table 3. Symptoms section of the SGRQ-C including comparisons between Biomass and LPG group for Cough, Phlegm production, Shortness of breath, and Wheezing.

\begin{tabular}{lcc}
\hline SGRQ-C Symptoms & Biomass $(\mathbf{n}=\mathbf{3 2})$ & LPG $(\mathbf{n}=\mathbf{2 8})$ \\
\hline Cough & & \\
Most days & $5(15.6)$ & $0(0.0)$ \\
Several days & $14(43.8)$ & $3(10.7)$ \\
Only with chest infections & $10(31.3)$ & $16(57.1)$ \\
Not at all & $3(9.4)$ & $9(32.1)$ \\
\hline Phlegm & & \\
Most days & $4(12.5)$ & $0(0.0)$ \\
Several days & $16(50.0)$ & $4(14.3)$ \\
Only with chest infections & $12(37.5)$ & $13(46.4)$ \\
Not at all & $0(0.0)$ & $11(39.3)$ \\
\hline Shortness of breath & & \\
Most days & $2(6.3)$ & $0(0.0)$ \\
Several days & $26(81.3)$ & $10(35.7)$ \\
Not at all & $4(12.5)$ & $18(64.3)$ \\
\hline Wheezing & & \\
Most days & $0(0.0)$ & $0(0.0)$ \\
Several days & $0(0.0)$ & $0(0.0)$ \\
Few days & $0(0.0)$ & $0(0.0)$ \\
Only with chest infections & $5(15.6)$ & $4(14.3)$ \\
Not at all & $27(84.4)$ & $24(85.7)$ \\
\hline
\end{tabular}

Table 4. Weighted scores for the SGRQ-C Symptoms section.

\begin{tabular}{cccc}
\hline Weighted Scores & Biomass $(\mathbf{n}=\mathbf{3 2})$ & LPG $(\mathbf{n}=\mathbf{2 8})$ & $\boldsymbol{p}$-Value \\
\hline Cough & $41.6(21.9)$ & $21.0(15.7)$ & $<0.001$ \\
\hline Phlegm & $44.4(14.7)$ & $20.7(17.9)$ & $<0.001$ \\
\hline Shortness of breath & $46.3(19.9)$ & $18.0(24.5)$ & $<0.001$ \\
\hline Wheezing & $5.7(13.4)$ & $5.2(13.0)$ & 0.887 \\
\hline
\end{tabular}

The mean mmRC score from the Biomass group was 2.9 compared to 0.5 in the LPG group $(p<0.001$; Table 2$)$. Results of the secondary analysis indicated that FeNO measurements were highly correlated with $\mathrm{mMRC}$ scores $(\mathrm{r}=0.80$; Figure 2$)$. 


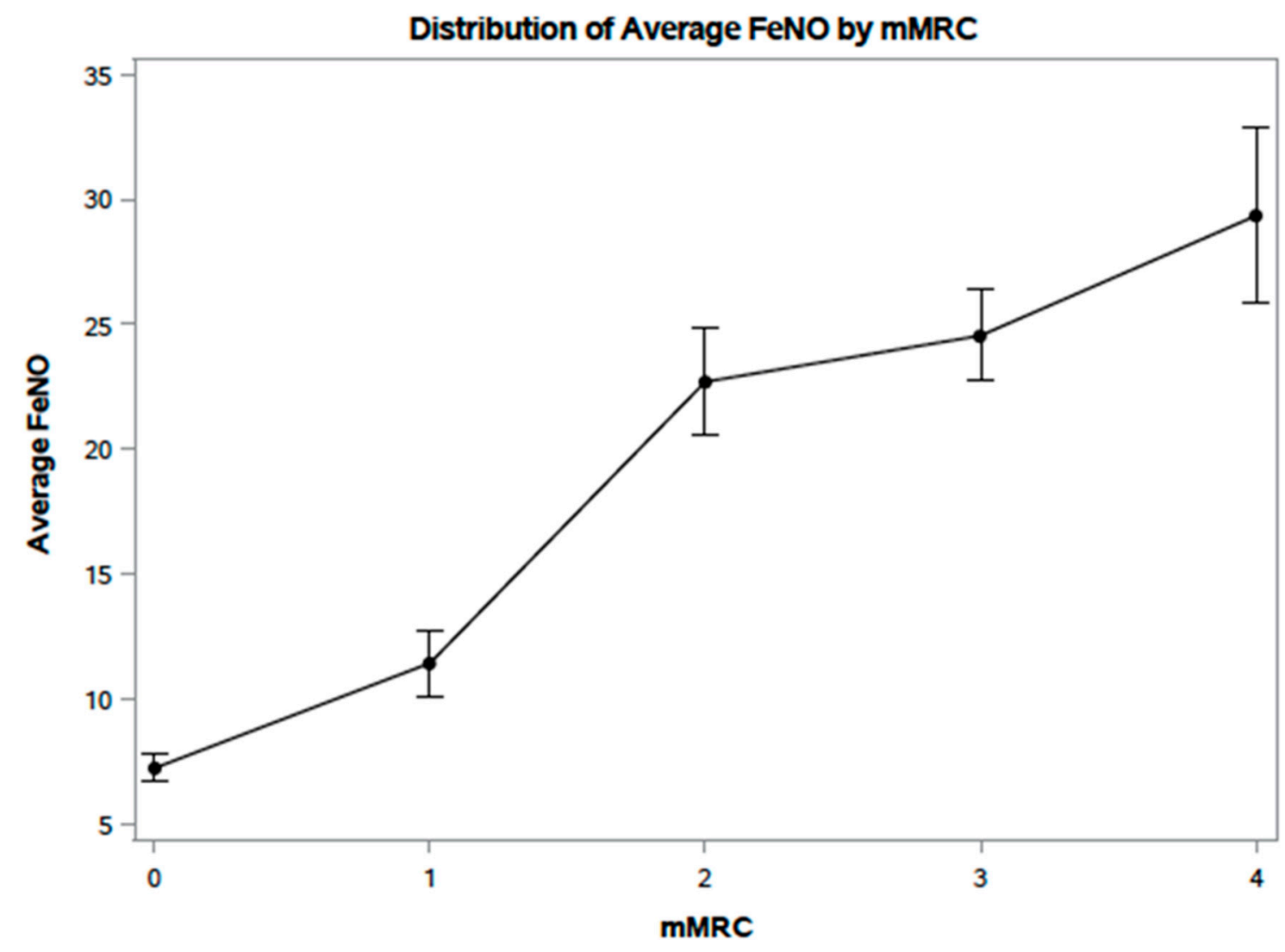

Figure 2. Scatter plot between FeNO results and mMRC dyspnea scale scores.

\section{Discussion}

Our cross-sectional study demonstrated increased prevalence of respiratory symptoms and airway inflammation, as measured by FeNO, among pregnant women using biomass fuel compared to those using LPG. Our study also provided a unique opportunity to evaluate correlations between the subjective respiratory assessment of dyspnea and FeNO levels.

\subsection{Respiratory Symptoms}

Prior studies evaluating the burden of respiratory symptoms among those exposed to biomass fuel have adapted various methodologies. A recent investigation into biomass fuel exposure by Pathak et al. adapted its own questionnaire designed specifically for the study, focusing on common respiratory symptoms such as cough, phlegm production, wheezing, and dyspnea [56]. While there remains significant overlap with validated questionnaires, this method lacks reproducibility in other, similarly framed studies. Meanwhile, the SGRQ has been utilized not only in India but also in other countries, including rural Bolivia, as a valuable tool to analyze the respiratory effects of HAP [57]. Our study adopted a two-prong method of assessing subjective symptoms using both a self-administered questionnaire and interviewer-administered dyspnea scale. This approach, which was utilized by Kurmi et al. in a biomass exposure study in Nepal, has a clear advantage in possibly avoiding challenges faced when using a translated questionnaire in a different cultural setting $[58,59]$. Not only did we utilize both the SGRQ-C and mMRC, but our study also found a correlation between subjective and objective measurements of mMRC and FeNO, respectively (Figure 2). This correlation works to expand on the concept that respiratory symptoms alone may be early indicators of chronic airway disease and early identification of these symptoms would allow for preventative care and intervention [60,61]. 


\section{2. $\mathrm{FeNO}$}

The evidence from our study supports the hypothesis that increased exposure to HAP is linked to airway inflammation as measured by FeNO. FeNO provides a noninvasive, safe, and accurate method for assessing the degree of airway inflammation in patients [62] However, prior studies have shown inconsistent findings: Benka-Coker et al. failed to show a connection between biomass cookstoves and FeNO measurements among Honduras women [63]. Similar null associations were seen in two other studies by Strak et al. and Yoda et al. [64,65]. Meanwhile, Berhane et al. and Liu et al., among others, have shown the utility of FeNO in assessing air pollution effects in children [40-42,66,67]. More recently, Tamasi et al. examined the role of FeNO in adults, including pregnant women and several additional investigations have followed course $[33,36-39,43]$. The reason for the inconsistent data regarding FeNO could be related to the technology available to assess exhaled NO. In particular, Benka-Coker et al. hypothesized that optimizing the flow rate within the device may provide a more accurate assessment of the proximal airways thereby increasing the accuracy of FeNO testing [63].

Our study contributes to the growing body of evidence that FeNO can be a useful tool in assessing the consequences of biomass fuel exposure on the respiratory system and thereby provide insight into the physiologic effects of toxic inhalation on the airways. Malerba et al. showed increased levels of NO synthase in airway epithelial cells of patients with asthma as well as reduced levels in those who are treated with inhaled corticosteroids [68]. Similarly, Olin et al. established that increasing values of FeNO are seen in those with atopic disease, with or without respiratory complaints [69]. Both Erpenbeck et al. and Brightling et al. have indicated a positive correlation between FeNO levels and eosinophil count on bronchoalveolar lavage fluid $[68,69]$. These prior investigations, in conjunction with the findings from our study, can help us better understand the physiologic changes that are taking place in the respiratory system as a result of biomass fuel exposure.

Given the emerging use of FeNO in air pollution studies on a global level as well as the results from our investigation where we established a correlation between $\mathrm{mMRC}$ and FeNO measurements, this tool shows great promise in helping identify those who have developed a degree of respiratory compromise as a result of HAP exposure.

\subsection{Strengths}

A major strength of our study is the comprehensive respiratory assessment of participants. All subjects completed a self-administered questionnaire, an intervieweradministered assessment of dyspnea, and an objective test to measure airway inflammation. This allows for a precise evaluation of the impact that HAP has on the pulmonary function of the subjects.

\subsection{Limitations}

Limitations of this study, first and foremost, arise from the fact that we did not directly measure pollutant concentrations and instead, used self-reported proxy for fuel use. Another factor was that we did not have information regarding each study participants' type of cookstove within the home. The effects of outdoor air pollution along with secondhand smoke exposure could have been a confounding factor as well but we did not have information that we could adjust for. The cross-sectional nature of the study design limits our ability to establish whether the exposure to biomass fuel preceded the evidence of airway inflammation. Lastly, the small sample size of our study is another limitation and could prevent the findings from being generalized to larger populations that are exposed to biomass fuel.

\section{Conclusions}

Reliance on biomass fuels as a primary source of household energy and the resultant $\mathrm{HAP}$, which is a modifiable risk factor, contribute directly to the high burden of respiratory disease in India. Elevated FeNO levels and higher dyspnea scores in biomass-fuel-exposed 
subjects confirm the adverse respiratory effects of this exposure during pregnancy, adding to previous findings among similar group of women. More so, FeNO may be a useful, noninvasive biomarker of inflammation that can help better understand the physiologic effects of biomass smoke on pregnant women. Further research is needed to characterize the physiologic utility of FeNO in a population exposed to HAP as a means of developing cost-effective strategies aimed at improving respiratory health.

Author Contributions: Conceptualization, R.P., S.R.R., R.K., G.T.O., A.P. and P.L.H.; Data curation, R.P., S.R.R., R.K. and P.L.H.; Formal analysis, R.P., S.R.R., R.K., G.T.O., A.P. and P.L.H.; Investigation, R.K. and G.T.O.; Methodology, R.P., S.R.R., R.K., G.T.O., A.P. and P.L.H.; Supervision, P.L.H.; Writingoriginal draft, R.P., S.R.R., G.T.O., A.P. and P.L.H.; Writing—review and editing, R.P., S.R.R., G.T.O., A.P. and P.L.H. All authors have read and agreed to the published version of the manuscript.

Funding: This research received no external funding.

Institutional Review Board Statement: The study was conducted according to the guidelines of the Declaration of Helsinki, and approved by the Insitutional Review Board of Boston University (H-38568; 5/28/2019).

Informed Consent Statement: Informed consent was obtained from all subjective involved in this study.

Conflicts of Interest: The authors declare no conflict of interest.

\section{References}

1. Mishra, V.K. Effect of indoor air pollution from biomass combustion on prevalence of asthma in the elderly. Environ. Health Perspect. 2003, 111, 71-78. [CrossRef] [PubMed]

2. Bonjour, S.; Adair-Rohani, H.; Wolf, J.; Bruce, N.G.; Mehta, S.; Prüss-Ustün, A.; Lahiff, M.; Rehfuess, E.A.; Mishra, V.; Smith, K.R. Solid Fuel Use for Household Cooking: Country and Regional Estimates for 1980-2010. Environ. Health Perspect. 2013, 121, 784-790. [CrossRef] [PubMed]

3. International Energy Agency. WEO-2017 Special Report: Energy Access Outlook; International Energy Agency: Paris, France, 2017.

4. Guilbert, J.J. The World Health Report 2002-Reducing Risks, Promoting Healthy Life; Educ Health: Abingdon, VA, USA, 2003; Volume 16, p. 230.

5. Smith, K.R. Fuel combustion, air-pollution exposure, and health-The situation in developing-countries. Annu. Rev. Energy Environ. 1993, 18, 529-566. [CrossRef]

6. Patel, A.B.; Meleth, S.; Pasha, O.; Goudar, S.S.; Esamai, F.; Garces, A.; Chomba, E.; McClure, E.M.; Wright, L.L.; Koso-Thomas, M.; et al. Impact of exposure to cooking fuels on stillbirths, perinatal, very early and late neonatal mortality-A multicenter prospective cohort study in rural communities in India, Pakistan, Kenya, Zambia and Guatemala. Matern. Health Neonatol. Perinatol. 2015, 1, 1-12. [CrossRef]

7. Patel, A.; Prakash, A.A.; Pusdekar, Y.V.; Kulkarni, H.; Hibberd, P.L. Detection and risk stratification of women at high risk of pre-term birth in rural communities near Nagpur, India. BMC Pregnancy Childbirth 2017, 17, 311. [CrossRef]

8. Page, C.M.; Patel, A.; Hibberd, P.L. Does Smoke from Biomass Fuel Contribute to Anemia in Pregnant Women in Nagpur, India? A Cross-Sectional Study. PLoS ONE 2015, 10, e0127890. [CrossRef]

9. Kleimola, L.B.; Patel, A.B.; Borkar, J.A.; Hibberd, P.L. Consequences of household air pollution on child survival: Evidence from demographic and health surveys in 47 countries. Int. J. Occup. Environ. Health 2015, 21, 294-302. [CrossRef]

10. Fullerton, D.G.; Bruce, N.; Gordon, S.B. Indoor air pollution from biomass fuel smoke is a major health concern in the develop-ing world. Trans. R Soc. Trop. Med. Hyg. 2008, 102, 843-851. [CrossRef]

11. Cohen, A.J.; Brauer, M.; Burnett, R.; Anderson, H.R.; Frostad, J.; Estep, K.; Balakrishnan, K.; Brunekreef, B.; Dandona, L.; Dandona, R.; et al. Estimates and 25-year trends of the global burden of disease attributable to ambient air pollution: An analysis of data from the Global Burden of Diseases Study 2015. Lancet 2017, 389, 1907-1918. [CrossRef]

12. Curtis, L.; Rea, W.; Smith-Willis, P.; Fenyves, E.; Pan, Y. Adverse health effects of outdoor air pollutants. Environ. Int. 2006, 32, 815-830. [CrossRef]

13. Mishra, V.; Retherford, R.D. Does biofuel smoke contribute to anemia and stunting in early childhood? Int. J. Epidemiol. 2007, 36, 117-129. [CrossRef] [PubMed]

14. Alexander, D.; Northcross, A.; Wilson, N.; Dutta, A.; Pandya, R.; Ibigbami, T. Randomized controlled ethanol cookstove intervention and blood pressure in pregnant Nigerian women. Am. J. Respir. Crit. Care Med. 2017, 195, 1629-1639. [CrossRef] [PubMed]

15. Amegah, A.K.; Quansah, R.; Jaakkola, J.J.K. Household Air Pollution from Solid Fuel Use and Risk of Adverse Pregnancy Outcomes: A Systematic Review and Meta-Analysis of the Empirical Evidence. PLoS ONE 2014, 9, e113920. [CrossRef] [PubMed]

16. Glinianaia, S.V.; Rankin, J.; Bell, R.; Pless-Mulloli, T.; Howel, D. Particulate air pollution and fetal health: A systematic review of the epidemiologic evidence. Epidemiology 2004, 15, 36-45. [CrossRef] 
17. Perera, F.P.; Whyatt, R.M.; Jedrychowski, W.; Rauh, V.; Manchester, D.; Santella, R.M. Recent developments in molecular epidemiology: A study of the effects of environmental polycyclic aromatic hydrocarbons on birth outcomes in Poland. Am. J. Epidemiol. 1998, 147, 309-314. [CrossRef]

18. Morello-Frosch, R.; Jesdale, B.M.; Sadd, J.L.; Pastor, M. Ambient air pollution exposure and full-term birth weight in California. Environ. Health 2010, 9, 44. [CrossRef]

19. Engel, S.M.; Erichsen, H.C.; Savitz, D.A.; Thorp, J.; Chanock, S.J.; Olshan, A.F. Risk of Spontaneous Preterm Birth is Associated With Common Proinflammatory Cytokine Polymorphisms. Epidemiology 2005, 16, 469-477. [CrossRef]

20. Ritz, B.; Wilhelm, M.; Hoggatt, K.J.; Ghosh, J.K.C. Ambient Air Pollution and Preterm Birth in the Environment and Pregnancy Outcomes Study at the University of California, Los Angeles. Am. J. Epidemiol. 2007, 166, 1045-1052. [CrossRef]

21. Pope, D.P.; Mishra, V.; Thompson, L.; Siddiqui, A.R.; Rehfuess, E.A.; Weber, M. Risk of low birth weight and stillbirth associ-ated with indoor air pollution from solid fuel use in developing countries. Epidemiol. Rev. 2010, 32, 70-81. [CrossRef]

22. Salam, M.T.; Millstein, J.; Li, Y.-F.; Lurmann, F.W.; Margolis, H.G.; Gilliland, F.D. Birth Outcomes and Prenatal Exposure to Ozone, Carbon Monoxide, and Particulate Matter: Results from the Children's Health Study. Environ. Health Perspect. 2005, 113, 1638-1644. [CrossRef]

23. Sangalli, M.; McLean, A.; Peek, M.J.; Rivory, L.P.; Le Couteur, D.G. Carbon Monoxide Disposition and Permeability-Surface Area Product in the Foetal Circulation of the Perfused Term Human Placenta. Placenta 2003, 24, 8-11. [CrossRef] [PubMed]

24. Di Cera, E.; Doyle, M.L.; Morgan, M.S.; De Cristofaro, R.; Landolfi, R.; Bizzi, B. Carbon monoxide and oxygen binding to hu-man hemoglobin F0. Biochemisty 1989, 28, 2631-2638. [CrossRef] [PubMed]

25. Bosley, A.R.; Sibert, J.R.; Newcombe, R.G. Effects of maternal smoking on fetal growth and nutrition. Arch. Dis. Child 1981, 56, 727-729. [CrossRef] [PubMed]

26. Bernstein, J.A.; Alexis, N.; Barnes, C.; Bernstein, I.L.; Nel, A.; Peden, D.; Diaz-Sanchez, D.; Tarlo, S.M.; Williams, P.B. Health effects of air pollution. J. Allergy Clin. Immunol. 2004, 114, 1116-1123. [CrossRef]

27. Anderson, J.O.; Thundiyil, J.G.; Stolbach, A. Clearing the Air: A Review of the Effects of Particulate Matter Air Pollution on Human Health. J. Med. Toxicol. 2012, 8, 166-175. [CrossRef]

28. Kelly, E.J.; Fussell, J.C. Air pollution and airway disease. Clin. Exp. Allergy 2011, 41, 1059-1071. [CrossRef]

29. Holgate, S.T.; Sandstrom, T.; Frew, A.J.; Stenfors, N.; Nordenhall, C.; Salvi, S. Health effects of acute exposure to air pollution. Part 1: Health and asthmatic subjects exposed to diesal exhaust. Res. Rep. Health Eff. Inst. 2003, 112, 1-30.

30. Van Eeden, S.F.; Tan, W.C.; Suwa, T.; Mukae, H.; Terashima, T.; Fuji, T. Cytokines involved in the systemic inflammatory re-sponse induced by exposure to particulate matter air pollutants (PM10). Am. J. Respir. Crit. Care Med. 2001, 164, 826-830. [CrossRef]

31. Barregard, L.; Sallsten, G.; Andersson, L.; Almstrand, A.C.; Gustafson, P.; Andersson, M. Experimental exposure to wood smoke: Effects on airway inflammation and oxidative stress. Occup. Environ. Med. 2008, 65, 319-324. [CrossRef]

32. Pope, D.; Diaz, E.; Smith-Sivertsen, T.; Lie, R.T.; Bakke, P.; Balmes, J.R. Exposure to household air pollution from wood combustion and association with respiratory symptoms and lung function in nonsmoking women: Results from the RESPIRE trial, Guatemala. Environ. Health Perspect. 2015, 123, 285-292. [CrossRef]

33. Swiston, J.R.; Davidson, W.; Attridge, S.; Li, G.T.; Brauer, M.; Van Eeden, S.F. Wood smoke exposure induces a pulmonary and sys-temic inflammatory response in firefighters. Eur. Respir. J. 2008, 32, 129-138. [CrossRef] [PubMed]

34. Huang, W.; Wang, G.; Lu, S.-E.; Kipen, H.; Wang, Y.; Hu, M.; Lin, W.; Rich, D.; Ohman-Strickland, P.; Diehl, S.R.; et al. Inflammatory and Oxidative Stress Responses of Healthy Young Adults to Changes in Air Quality during the Beijing Olympics. Am. J. Respir. Crit. Care Med. 2012, 186, 1150-1159. [CrossRef] [PubMed]

35. Van Amsterdam, J.G.; Verlaan, B.P.; Van Loveren, H.; Elzakker, B.G.; Vos, S.G.; Opperhuizen, A. Air pollution is associated with increased level of exhaled nitric oxide in nonsmoking healthy subjects. Arch. Environ. Health 1999, 54, 331-335. [CrossRef] [PubMed]

36. Xu, T.; Hou, J.; Cheng, J.; Zhang, R.; Yin, W.; Huang, C.; Zhu, X.; Chen, W.; Yuan, J. Estimated individual inhaled dose of fine particles and indicators of lung function: A pilot study among Chinese young adults. Environ. Pollut. 2018, 235, 505-513. [CrossRef]

37. Shi, J.; Chen, R.; Yang, C.; Lin, Z.; Cai, J.; Xia, Y. Association between fine particulate matter chemical constituents and air-way inflammation: A panel among health adults in China. Enivron. Res. 2016, 150, 264-268. [CrossRef]

38. Idavain, J.; Julge, K.; Rebane, T.; Lang, A.; Orru, H. Respiratory symptoms, asthma and levels of fractional exhaled nitric oxide in school children in the industrial areas of Estonia. Sci. Total. Environ. 2019, 650, 65-72. [CrossRef]

39. Graveland, H.; Van Roosbroeck, S.A.; Rensen, W.M.; Brunekreef, B.; Gehring, U. Air pollution and exhaled nitric oxide in Dutch school children. Occup. Environ. Med. 2011, 68, 551-556. [CrossRef]

40. La Grutta, S.; Ferrante, G.; Malizia, V.; Cibella, F.; Viegi, G. Environmental effects on fractional exhaled nitric oxide in allergic children. J. Allergy 2012, 2012, 916926. [CrossRef]

41. Tamasi, L.; Bohacs, A.; Bikov, A.; Andorka, C.; Losonczyy, G.R., Jr. Exhaled nitric oxide in pregnant healthy and asth-matic women. J. Asthma 2009, 46, 786-791. [CrossRef]

42. Fahy, J.V. Eosinophilic and Neutrophilic Inflammation in Asthma: Insights from Clinical Studies. Proc. Am. Thorac. Soc. 2009, 6, 256-259. [CrossRef]

43. Barnes, P.J.; Dweik, R.A.; Gelb, A.F.; Gibson, P.G.; George, S.C.; Grasemann, H. Exhaled nitric oxide in pulmonary diseases: A comprehensive review. Chest 2010, 138, 682-692. [CrossRef] [PubMed] 
44. Possa, S.S.; Leick, E.A.; Prado, C.M.; Martins, M.A.; Tibério, I.D.F.L.C. Eosinophilic Inflammation in Allergic Asthma. Front. Pharmacol. 2013, 4, 46. [CrossRef] [PubMed]

45. Zamora, R.; Vodovotz, Y.; Billiar, T.R. Inducible Nitric Oxide Synthase and Inflammatory Diseases. Mol. Med. 2000, 6, 347-373. [CrossRef] [PubMed]

46. Allen, B.W.; Demchenko, I.T.; Piantadosi, C.A. Two faces of nitric oxide: Implications for cellular mechanisms of oxygen tox-icity. J. Appl. Physiol. 2009, 106, 662-667. [CrossRef]

47. D'Sa, A.; Murthy, K.N. LPG as a cooking fuel option for India. Energy Sustain. Dev. 2004, 8, 91-106. [CrossRef]

48. Mohsen, S.; Hanafy, F.Z.; Fathy, A.A.; El-Gilany, A.-H. Nonadherence to treatment and quality of life among patients with chronic obstructive pulmonary disease. Lung India 2019, 36, 193-198. [CrossRef]

49. Pyasi, K.; Brashier, B.; Londhe, J.; Das, V.; Bulsara, N.; Moitra, S. Association between quality of life as assessed by St. George's respiratory questionnaire (SGRQ), lung function indices and sputum inflammatory parameters in Indian COPD patients. Eur. Resp. J. 2014, 44, 2189.

50. Pati, S.; Swain, S.; Patel, S.K.; Chauhan, A.S.; Panda, N.; Mahapatra, P.; Pati, S. An assessment of health-related quality of life among patients with chronic obstructive pulmonary diseases attending a tertiary care hospital in Bhubaneswar City, India. J. Fam. Med. Prim. Care 2018, 7, 1047-1053.

51. Meguro, M.; Barley, E.A.; Spencer, S.; Jones, P.W. Development and Validation of an Improved, COPD-Specific Version of the St. George Respiratory Questionnaire. Chest 2007, 132, 456-463. [CrossRef]

52. Jones, P.W.; Quirk, F.H.; Baveystock, C.M. The St George's Respiratory Questionnaire. Respir. Med. 1991, 85, 25-31. [CrossRef]

53. Bestall, J.C.; Paul, E.A.; Garrod, R.; Garnham, R.; Jones, P.W.; Wedzicha, J.A. Usefulness of the Medical Research Council (MRC) dyspnoea scale as a measure of disability in patients with chronic obstructive pulmonary disease. Thorax 1999, 54, 581-586. [CrossRef] [PubMed]

54. Suri, J.C.; Pathak, U.; Kumar, R.; Suri, T.M.; Gupta, N.C.; Pathak, S. Impact of biomass fuel exposure from traditional stoves on lung functions in adult women of a rural Indian village. Lung India 2019, 36, 376-383. [CrossRef] [PubMed]

55. Alexander, D.; Linnes, J.C.; Bolton, S.; Larson, T. Ventilated cookstoves associated with improvements in respiratory health-related quality of life in rural Bolivia. J. Public Health 2013, 36, 460-466. [CrossRef] [PubMed]

56. Kurmi, O.P.; Semple, S.; Devereux, G.S.; Gaihre, S.; Lam, K.B.; Sadhra, S. The effect of exposure to biomass smoke on respira-tory symptoms in adult rural and urban Nepalese populations. Environ. Health 2014, 13, 92. [CrossRef]

57. KalagoudaMahishale, V.; Angadi, N.; Metgudmath, V.; Lolly, M.; Eti, A.; Khan, S. The prevalence of chronic obstructive pulmonary disease and the determinants of underdiagnosis in women exposed to biomass fuel in India-A cross section study. Chonnam. Med. J. 2016, 52, 117-122. [CrossRef]

58. Van Vilet, E.D.S.; Kinney, P.L.; Owusu-Agyei, S.; Schluger, N.W.; Ae-Ngibise, K.A.; Whyatt, R.M. Current respiratory symptoms and risk factors in pregnant women cooking with biomass fuels in rural Ghana. Environ. Int. 2019, 124, 533-540. [CrossRef]

59. Woodruff, P.G.; Barr, R.G.; Bleecker, E.; Christenson, S.A.; Couper, D.; Curtis, J.L.; Gouskova, N.A.; Hansel, N.N.; Hoffman, E.A.; Kanner, R.E.; et al. Clinical Significance of Symptoms in Smokers with Preserved Pulmonary Function. N. Engl. J. Med. 2016, 374, 1811-1821. [CrossRef]

60. Dweik, R.A.; Boggs, P.B.; Erzurum, S.C.; Irvin, C.G.; Leigh, M.W.; Lundberg, J.O. An official ATS clinical practice guideline: In-terpretation of exhaled nitric oxide levels (FENO) for clinical applications. Am. J. Respir. Crit. Care Med. 2011, 184, 602-615. [CrossRef]

61. Benka-Coker, M.L.; Clark, M.L.; Rajkumar, S.; Young, B.N.; Bachand, A.M.; Balmes, J.R.; Brook, R.D.; Nelson, T.L.; Volckens, J.; Reynolds, S.J.; et al. Exposure to Household Air Pollution from Biomass Cookstoves and Levels of Fractional Exhaled Nitric Oxide (FeNO) among Honduran Women. Int. J. Environ. Res. Public Health 2018, 15, 2544. [CrossRef]

62. Strak, M.; Boogaard, H.; Meliefste, K.; Oldenwening, M.; Zuurbier, M.; Brunekreef, B.; Hoek, G. Respiratory health effects of ultrafine and fine particle exposure in cyclists. Occup. Environ. Med. 2009, 67, 118-124. [CrossRef]

63. Yoda, Y.; Otani, N.; Sakurai, S.; Shima, M. Acute effects of summer air pollution on pulmonary function and airway inflamma-tion in healthy young women. J. Epidemiol. 2014, 24, 312-320. [CrossRef]

64. Berhane, K.; Zhang, Y.; Salam, M.T.; Eckel, S.P.; Linn, W.S.; Rappaport, E.B. Longitudinal effects of air pollution on exhaled ni-tric oxide; The Children's Health Study. Occup. Environ. Med. 2014, 71, 507-513. [CrossRef]

65. Liu, C.; Flexeder, C.; Fuertes, E.; Cyrys, J.; Bauer, C.-P.; Koletzko, S.; Hoffmann, B.; Von Berg, A.; Heinrich, J. Effects of air pollution on exhaled nitric oxide in children: Results from the GINIplus and LISAplus studies. Int. J. Hyg. Environ. Health 2014, 217, 483-491. [CrossRef] [PubMed]

66. Malerba, M.; Radaeli, A.; Olivini, A.; Damiani, G.; Ragnoli, B.; Montuschi, P.; Ricciardolo, F.L.M. Exhaled Nitric Oxide as a Biomarker in COPD and Related Comorbidities. BioMed Res. Int. 2014, 2014, 1-7. [CrossRef] [PubMed]

67. Olin, A.-C.; Rosengren, A.; Thelle, D.S.; Lissner, L.; Bake, B.; Torén, K. Height, Age, and Atopy Are Associated with Fraction of Exhaled Nitric Oxide in a Large Adult General Population Sample. Chest 2006, 130, 1319-1325. [CrossRef] [PubMed]

68. Erpenbeck, V.J.; Jörres, R.A.; Discher, M.; Krentel, H.; Tsikas, D.; Luettig, B. Local nitric oxide levels reflect the degree of aller-gic airway inflammation after segmental allergen challenge in asthmatics. Nitric Oxide 2005, 13, 125-133. [CrossRef] [PubMed]

69. Brightling, C.E.; Symon, F.A.; Birring, S.S.; Bradding, P.; Wardlaw, A.J.; Pavord, I.D. Comparison of airway immunopathology of eosinophilic bronchitis and asthma. Thorax 2003, 58, 528-532. [CrossRef] [PubMed] 